vegetables, cereals, fruit, ornamental plants, etc., whilst the causal agents are listed in the orderViruses, Bacteria, Myxomycetes, Phycomycetes, Ascomycetes, Basidiomycetes, Fungi Imperfecti, and Non-parasitic. Foreign names are also given where possible. The comprehensive orderliness of the list should commend it for universal adoption.

\section{Acta Physicochimica U.R.S.S.}

THE publication of the Acta Physicochimica U.R.S.S. commenced in September 1934, and volume I containing six parts has just been completed. In Russia as in other countries, the ramifications of chemistry, especially in its mathematical and physical aspects, are growing so complex and varied that it is found desirable to have as a medium for publication, in addition to the usual journals devoted to chemistry, a special one devoted to the more advanced aspects of physical and theoretical chemistry. We have noted the recent appearance of the Journal of Chemical Physics in the United States, the remarkably effective and somewhat sudden renaissance of the Transactions of the Faraday Society in Great Britain, and now the appearance of the Acta Physicochimica in Russia. The board of editors of the journal is certainly to be congratulated on the first six parts. It would appear that the referees appointed by the board function admirably in that country in selecting suitable--and presumably also in rejecting unsuitable-material. A number of internationally well-known names, including those particularly well known in England, Profs. Frenkel, Frumkin, Rabinovitch, Semenoff and Talmud, are to be found on the board, and there is a list of some forty permanent contributors distributed over seven cities of the U.S.S.R. Although new journals furnish problems both in budgeting and in library accommodation, these difficulties will be overcome at least for this admirable example of a specialised scientific journal.

\section{Insects of Samoa}

THe British Museum (Natural History) has recently issued further instalments of the publication entitled "Insects of Samoa", a work which has been noticed from time to time in these columns. Part 6, Fasc. 8 of the complete work, by Mr. J. R. Malloch, of the U.S. Bureau of Biological Survey, deals with some further groups of Acalypterate flies, namely, the families Irosophilidæ, Ephydridæ, Sphaeroceridæ and Milichiidæ, and is illustrated by 16 text-figures. In Part 6, Fasc. 9, Mr. Malloch discusses certain families of Cyclorrhaphous flies, namely, Phoridæ, Agromyzidæ, Micropezidæ, Tachinidæ and Sarcophagidæ (supplement). Dr. H. H. Knight, of the Iowa State College, deals with the hemipterous families Miridæ and Anthocoridæ (Part 2, Fasc. 5), which comprise 21 genera and 33 species. Part 3, Fasc. 4 is by $\mathrm{Mr}$. W. H. T. Tams of the British Museum (Natural History), who contributes a lengthy section comprising all the Heterocera, excepting the Geometridæ and Microlepidoptera, which have already been reported upon. Mr. Tams's report more than trebles the number of Samoan moths represented in the British
Museum. It also contains important observations on nomenclature and upon the grouping of the subfamily divisions of Heterocera.

\section{Field Museum of Chicago}

Tre economic situation in the United States is bearing heavily upon institutes such as museums which depend largely upon the goodwill and financial aid of the people. The annual report for 1934 of the Director of the Field Museum of Natural History shows this clearly. Income, from endowments, tax collections, admissions and membership, was in each case reduced, so that a total of 491,002 dollars stands against 636,318 for 1933 . Visitors have fallen from more than three millions in 1933 to less than two millions in 1934, though the earlier year's numbers were abnormally increased by the opening of the "Century of Progress Exposition" in Chicago. In spite of difficulties, the Field Museum continues to prosecute research in various fields, though these are now limited to privately financed expeditions; it has added notable groups of animals to its public galleries; and it continues by means of lectures (attended by some 662,000 persons, mostly children) and by travelling natural history exhibits (to more than four hundred schools) to educate the youth of Chicago biologically.

\section{Examinations in Milk Processing and Control}

The City and Guilds of London Institute has arranged to hold examinations in the future, commencing May next year, in milk processing and control, with certification of successful candidates. It is hoped that the provision of the examinations will encourage the formation of classes of instruction in these subjects in different parts of Great Britain, so that those engaged in the milk industry who receive such instruction should be in a position to render more efficient service. It is proposed that the examinations should be held at approved centres in Great Britain, Ireland and overseas. The syllabus of the examination for the certificate, which will be in two parts, intermediate and final, has been drawn up by a representative advisory committee, and may be obtained from the Superintendent, Department of Technology, City and Guilds of London Institute, 31 Brechin Place, South Kensington, London, S.W.7.

\section{The Seismological Station of De Bilt}

WE have received the valuable report on the earthquakes recorded at this well-known observatory during the year 1932. The instruments include horizontal and vertical component Galitzin seismographs and also Wiechert and Bosch seismographs. In addition to a catalogue of 437 earthquakes, the report contains an appendix on the earthquakes in North Brabant during November 20-28, 1932. The principal earthquake occurred on November 20 and was felt all over the Netherlands, in Belgium and west Germany, and even, it is said, in London. Its epicentre (in lat. $51^{\circ} 40^{\prime} \mathrm{N}$., long. $5^{\circ} 35^{\prime} \mathrm{E}$.), as well as the epicentres of three strong after-shocks, lay close to the boundaries of the central rift-valley. 